\title{
PENDAMPINGAN PEMBUATAN PUPUK MOL MASAYARAKAT DESA
}

\author{
Akbal Yaladjuna ${ }^{1}$ Lutpi Samaduri $^{2}$ \\ ${ }^{1}$ Fakultas pertanian Universitas muhammadiyah Luwuk \\ Email : akbal.yalajuna19@gmail.com \\ Universitas Muhammadiyah Luwuk \\ Email : lutpi@unismuhluwuk.ac.id
}

\begin{abstract}
ABSTRAK
Tujuan pelaksanaan kegiatan ini yaitu untuk meningkatan pengetahuan dan pemahaman masyarakat dalam proses pembuatan pupuk mol berbahan dasar bonggol pisang, rembung bambu, dan buah pepaya.

Kegiatan ini dilaksanakan pada bulan Februari sampai bulan Maret 2019, bertempat di rumah warga dusun I, dusun II, dusun III, dan dusun IV desa Toliba kecamatan Tojo barat kabupaten Tojo una-una. Pada tahap awal pelaksanaan program yang di laksanakan kegiatan sosialisai tentang pelaksanaan kegiatan pembuatan pupuk mol, persiapan alat dan bahan, kemudian dilanjutka dengan pelaksanaan kegiatan pelatihan pembuatan MOL.

Hasil yang didapatkan yakni pelaksanaan program mampu menghasilkan luaran-luaran yang diharapkan oleh program pengabdian kepada masyarakat yakni meningkatnya pengetahuan masyarakat Desa Toliba dalam pembuatan MOL dengan memanfaatkan potensi yang ada. Serta Meningkatnya pemahaman masyarakat tentang pemanfaatan bahan dasar (Bonggol Pisang, Rebung bambu dan Buah Pepaya) untuk dijadikan sebagai salah satu alternatif pupuk organik bagi tanaman.
\end{abstract}

Kata kunci: MOL, Limbah Organik, Pendampingan .

\section{PENDAHULUAN}

Mikroorganisme lokal (MOL) merupakan bioaktivator cair berbahan baku organik untuk mempercepat proses pengomposan. Kelebihan lain dari MOL adalah biaya pembuatannya murah atau bahkan tanpa biaya. Bagi lingkungan hidup seperti tanah, adanya mikroorgansime dapat menentukan tingkat kesuburan tanah dan memperbaiki kondisi tanah. Metode pemupukan dalam pertanian organik sebenarnya bertumpu pada peran mikroorganisme. Mikoorganisme ini sebenarnya sangat muda dibudidyakan dan dikienal sebagai mikroorganisme lokal (MOL). Istilah lain dari MOL diantaranya starter, aktivator kompleks, mikroorganisme dekomposisi, bioaktivator dan dekomposer.

Berdasarkan kegunaannya dalam dunia pertanian mikroorganisme yang dapat dimanfaatkan untuk pembuatan pupuk organik dan kompos dapat ditemukan dari dalam tanah, tubuh hewan, limbah/sampah. Proses dekomposisi bahan organik terkait aktivitas bakteri merubah bahan organik menjadi kompos memerlukan bakteri untuk mempercepat prosesnya. Secara alami proses dekomposisi memerlukan waktu hingga 1-2 bulan tetapi dengan bantuan mikroorganismel lokal (MOL) proses dekomposisi hanya memerlukan waktu 7-14 hari.

Larutan MOL (Mikro Organisme Lokal) adalah hasil fermentasi yang berbahan dasar dari berbagai sumber daya yang tersedia ditempat. larutan MOL mengandung unsur hara mikro dan makro dan juga mengandung bakteri yang berpotensi sebagai perombak bahan organik, perangsang pertumbuhan, dan sebagai agen pengendali penyakit tanaman, sehingga MOL dapat digunakan baik sebagai dekomposer, pupuk hayati dan sebagai pestisida organik terutama sebagai fungisida. Bahan dasar pembuatan MOL yang paling banyak digunakan antara lain Bonggol Pisang, Rebung Bambu dan buah - buahan. 
Kandungan gizi bonggol pisang berpotensi digunakan sebagai sumber mikroorganisme lokal (MOL) karena kandungan gizi dalam bonggol pisang dapat digunakan sebagai sumber makanan sehingga mikrobia berkembang dengan baik. Jenis Mikroorganisme yang telah didentifikasi pada bonggol pisang antara lain Bacillus sp., Aeromonas sp., Aspergillus nigger, Azospirillium, Azotobacter dan mikroba selulolitik. Mikroba inilah yang biasa bertindak sebagai dekomposer bahan organik. Bonggol pisang mengandung gizi yang cukup tinggi dengan komposisi yang lengkap dalam 100 gram bonggol pisang basah terkandung 43,0 kalori, 0,36 g protein, 11,60 g karbohidrat, 86,0 g air, beberapa mineral.

Menurut Maspari (2012), larutan mol rebung bambu mempunyai kandungan C organik dan giberelin yang tinggi hingga mampu meransang pertumbuhan tanaman. Selain itu larutan MOL rebung bambu juga mengandung mikro organisme yang sangat penting untuk membantu pertumbuhan tanaman yaitu Azotobacter dan Azospirillum. Jika diliat dari kandungannya, larutan MOL rebung bamabu bisa digunakan sebagai perangsang pertumbuhan pada fase Vegetatif. seperti cA, P dan Fe, Vitamin B1 dan C, serta bebas kandungan lemak.

Rebung bambu merupakan tunas muda yang berasal dari tanaman bambu. Tunas muda ini biasanya tumbuh diantara batang-batang bambu yang sudah dewasa dengan warna kulit yang hitam pekat dan memiliki bulu-bulu halus yang gatal. Pada umumnya masyarakat di desa Toliba menggunakan rebung bambu sebagai sayuran karena rasanya yang enak dan ekonomis karna mudah didapat dan mudah tumbuh dimana saja. Tetapi rebung bambu ternyata dapat dijadikan sebagai bahan dasar dalam pembuatan larutan mikro organisme lokal (MOL).

untuk buah-buahan, buah pepaya banyak ditemukan di area-area perkebunan warga desa Toliba, masyarakat desa Toliba memanfaatkan buah pepaya untuk dikonsumsi pada saat matang dan sebagian masyarakat memanfaatkan buah pepaya yang masi muda di olah menjadi sayuran. buah tersebut tergolong buah yang mudah busuk sehingga banyak dibuang begitu saja dan menjadi limbah yang kurang bermanfaat. Limbah buah pepaya memiliki potensi yang baik dan dapat diolah menjadi pupuk organik cair untuk membantu memberi nutrisi bagi pertumbuhan tanaman. Buah pepaya mengandung karbohidrad, kalsium, magnesium dan fosfor yang tinggi, selain itu kadar nitrogen didalamnya pun tinggi (Nisa, 2016).

Sebagai salah satu campuran MOL air hasil cucian beras selama ini hanya dibuang saja setelah mencuci beras, padahal air cucian beras banyak mengandung unsur hara yang dibutuhkan oleh tanaman untuk tumbuh. Menurut Leonardo (2009), air cucian beras berpengaruh terhadap peningkatan jumlah daun dan tinggi tanaman tomat dan terung. Salah satu kandungan air cucian beras adalah fosfor. Fosfor berperan dalam pembentukan bunga dan buah, bahan pembentuk inti sel dan dinding sel, mendorong pertumbuhan akar muda dan pemasakan biji pembentukan klorofil, penting untuk enzim-enzim pernapasan, pembentukan klorofil, dan berfungsi untuk pengangkutan energi hasil metabolisme dalam tanaman (Liferdi, 2008).

Air kelapa merupakan salah satu produk tanaman yang dapat dimanfaatkan untuk meningkatkan pertumbuhan tanaman. Pada umumnya masyarakat petani kelapa di desa Toliba tidak memanfaatkan air kelapa dari hasil pemanenan, tidak ada salahnya bila dimanfaatkan sebagai penyiram tanaman. Hasil penelitian menunjukkan bahwa air kelapa kaya akan kalium, mineral diantaranya Kalsium (Ca), Natrium (Na), Magnesium (Mg), Ferum (Fe), Cuprum (Cu), dan Sulfur (S), gula dan protein. Disamping kaya mineral, dalam air kelapa juga terdapat 2 hormon alami yaitu auksin dan sitokinin yang berperan sebagai pendukung pembelahan sel (Suryanto,2009).

Dengan ketersediaan bahan dasar pembuat MOL di Desa Toliba yang melimpah dan selama ini tidak dimanfaatkan oleh masyarakat bahkan menjadi limbah, maka kegiatan pendampingan kepada masyarakat dalam pembuatan MOL perlu untuk dilakukan dengan mamanfaatkan potensi sumberdaya yang tersedia disekitar desa. 


\section{TUJUAN}

Tujuan pelaksanaan kegiatan ini yaitu untuk meningkatan pengetahuan dan pemahaman masyarakat dalam proses pembuatan pupuk mol berbahan dasar bonggol pisang, rembung bambu, dan buah pepaya.

\section{METODE}

\section{Waktu Dan Tempat Pelaksanaan Kegiatan}

Kegiatan ini dilaksanakan pada bulan Februari sampai bulan Maret 2019, bertempat di rumah warga dusun I, dusun II, dusun III, dan dusun IV desa Toliba kecamatan Tojo barat kabupaten Tojo una-una.

\section{Alat dan Bahan}

Adapun alat-alat yg di pergunakan dalam kegiatan pembuatan pupuk Mol (Mikroorganisme Lokal) yaitu parang, linggis, karet pengikat, ember, kertas koran, jergen 5 Liter, pisau, lesung kayu, baskom dan karung. Sedangkan bahan yang digunakan yaitu bonggol pisang, rebung bambu, buah pisang, buah pepaya, air kelapa, air leri (air cucian beras), dan gula merah.

\section{Prosedur Kerja}

Pada tahap pelaksanaan kegiatan dimulai dengan sosialisasi kepada masyarakat sasaran di desa Toliba Kecamatan Tojo barat Kabupaten Tojo una-una, di lanjutkan dengan pelaksanaan kegiatan-kegiatan pelatihan. Tahapan-tahapan dengan metode pelaksanaan kegiatan disajikan pada tabel berikut.

Tabel : Metode pelaksanaan kegiatan.

\begin{tabular}{|l|l|l|l|}
\hline \multicolumn{1}{|c|}{$\begin{array}{c}\text { Tahapan } \\
\text { Pelaksanaan }\end{array}$} & \multicolumn{1}{|c|}{ Kegiatan } & \multicolumn{1}{c|}{ Metode } & \multicolumn{1}{c|}{ Materi } \\
\hline Persiapan & $\begin{array}{l}\text { Sosialisasi } \\
\text { kemasyaraat } \\
\text { desa }\end{array}$ & $\begin{array}{l}\text { Pertemuaan dengan } \\
\text { Masyarakat }\end{array}$ & $\begin{array}{l}\text { Hal-hal yang perlu } \\
\text { dilakukan dalam } \\
\text { pembuatan pupuk mol }\end{array}$ \\
\hline Pelaksanaan & pelaksanaan & Partisipatif & $\begin{array}{l}\text { - Pelatihan tata cara } \\
\text { pembuatan pupuk mol } \\
\text { pelatihan teknis }\end{array}$ \\
& & $\begin{array}{l}\text { Proses penyaringan pupuk } \\
\text { mol dan penempatan di } \\
\text { wadah. }\end{array}$ \\
\hline
\end{tabular}

\section{HASIL DAN PEMBAHASAN}

Pelaksanaan kegiatan Pendapingan pembuatan pupuk MOL Masyarakat Desa Toliba Kecamatan Tojo barat Kabupaten Tojo una-una sampai pada bulan Maret 2019 telah di laksanakan 100\% program yaitu: sosialisai mengenai pelaksanaan kegiatan pembuatan pupuk mol, mempersiapkan alat dan bahan untuk memperlancar kegiatan, pelatihan tata cara pembuatan pupuk mol, proses penyaringan dan penempatan di wadah.

Pada tahap awal pelaksanaan program yang di laksanakan kegiatan sosialisai tentang pelaksanaan kegiatan pembuatan pupuk mol, persiapan alat dan bahan, dan kegiatan pelatihan. Sosialisai dan kegiatan pelatihan dilaksanakan bersama masyarakat, sehingga dalam proses pembuatan pupuk mol dapat berjalan dengan baik serta masyarakat dapat memahami proses pembuatannya.

\section{A. Sosialisasi mengenai pelaksanaan kegiatan pembuatan pupuk mol}

Kegiatan ini di laksanakan pada bulan februari 2019, bertempat di rumah warga desa Toliba Kecamatan Tojo Barat Kabupaten Tojo Una-Una. Peserta kegiatan adalah ketua kelompok tani dan masyarakat desa Toliba. Tujuan dari kegiatan ini untuk meningkatkan pengetahuan masyarakat dalam pembuatan pupuk mol dari bahan bonggol pisang, rebung bambu, dan buah pepaya. 


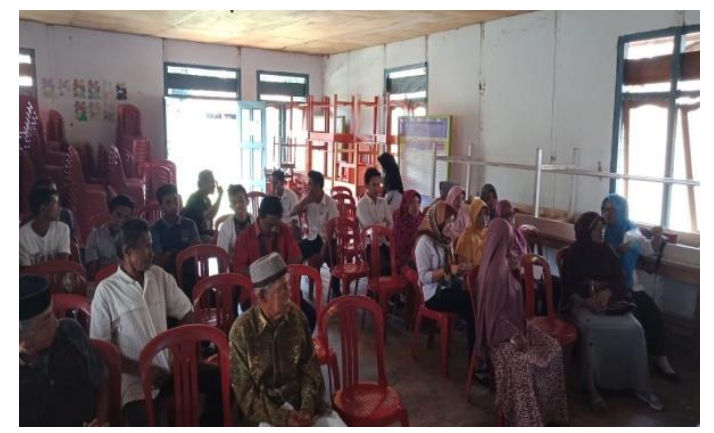

Gambar 1. Sosialisasi Mengenai Mekanisme Pelaksanaan Kegiatan Pendampingan Pembuatan Pupuk Mol

Kegiatan sosialisasi mengenai mekanisme pelaksanaan kegiatan pendampingan pembuatan pupuk mol diharapkan kedepannya masyarakat desa Toliba sudah lebih mengetahui cara pembuatan pupuk mol yang punya banyak manfaat bagi tanaman dan tidak mengeluarkan biaya banyak untuk pembuatannya.

\section{B. Pelatihan teknik pembuatan pupuk mol}

\section{Teknik pembuatan pupuk mol}

Pelatihan teknik pembuatan pupuk mol di desa Toliba Kecamatan Tojo Barat Kabupaten Tojo Una-Una dilaksanakan pada tanggal 6, 9, 12, dan 15 februari 2019 di rumah warga desa Toliba (Dusun I, Dusun II, Dusun III, Dan Dusun IV). Pelatihan ini bertujuan untuk meningkatan pengetahuan dan pemahaman masyarakat dalam pembuatan pupuk mol berbahan dasar bonggol pisang, rebung bambu dan buah pepaya yang banyak tersedia di sekitar lingkungan masyarakat. Gambar kegiatan pelatihan teknik pembuatan pupuk mol disajikan pada Gambar 2 dan Gambar 3.

Kegiatan pelatihan teknik pembuatan pupuk mol yang pertama yaitu melakukan pencacahan bahan dasar (bonggol pisang, rebung bambu dan buah pepaya), kemudian masukan bahan-bahan yang sudah dicacah kedalam ember, setelah itu masukan air cucian beras dan air kelapa kedalam ember yang sudah berisi baha-bahan dasar mol yang sudah di cacah sebelumnya, kemudian isi gula merah yang sudah di cairkan ke dalam ember, lalu campurkan seluruh dengan cara mengaduk menggunakan tangan hingga tercampur rata, setelah semua bahan tercampur dengan rata, wadah yang berisi campuran bahan tersebut ditutup dengan keadaan kedap udara (tidak ada udara) selama 2 minggu (akan tetapi penutup wadah tersebut dibuka satu kali setap hari untuk mengeluarkan gas). Jika sudah mencapai 2 minggu pupuk akan mengeluarkan bau seperti bau tape dan terdapat beberapa mikroorganisme di dalam campuran bahan-bahan pupuk mol, hal ini menggambarkan bahwa pupuk mol telah jadi tetapi belum siap untuk digunakan. Adapun respon dari setiap warga mengikuti kegiatan ini sangat mendukung agar masyarakat desa Totliba dapat melakukan terus menerus dalam pembuatannya.

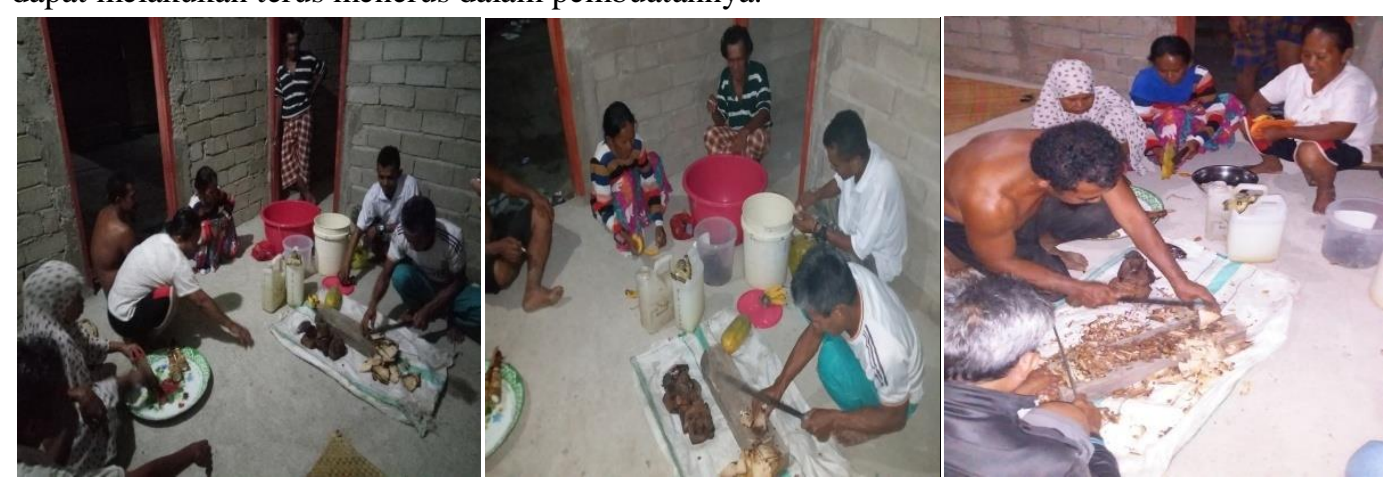




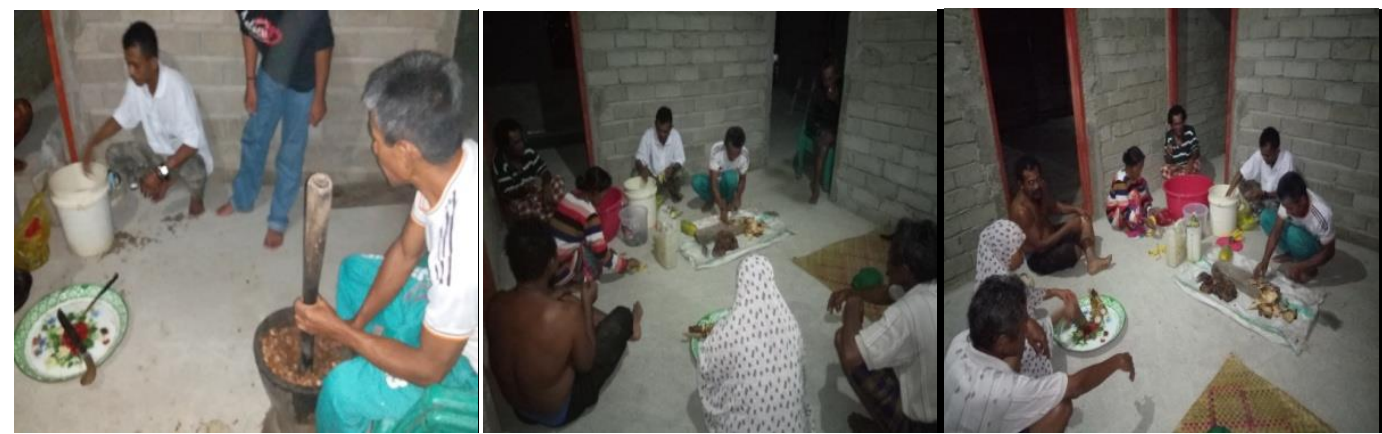

Gambar 2. Tehnik Pembuatan Pupuk Mol

\section{Penyaringan pupuk MOL}

Penyaringan pupuk mol di Desa Toliba Kecamatan Tojo Barat dilaksanakan pada tanggal 20, 23, 26 Februari dan 1 Maret 2019. Penyaringan pupuk mol adalah proses terakhir dalam pembuatan pupuk mol. Adapun hal-hal yang perlu dilakukan dalam proses penyaringan yaitu pertama angkat bahan-bahan pembuatan pupuk mol yang terdapat didalam wadah seperti bonggol pisang, tebung bambu, dan buah-buahan hingga menyisahkan airnya saja. Kemudian saring air tersebut hingga tidak terdapat ampas-ampas bonggol pisang, rebung bambu, buah-buahan dan mikroorganisme yang ada, lakukanlah proses penyaringan hingga 2 kali sampai terlihat benarbenar bersih. Setelah proses penyaringan selesai, pupuk mol yang sudah disaring tadi di pindahkan ke masing-masing wadah atau botol yang sudah di siapkan. Setelah semua proses selesai, maka proses pembuatan pupuk mol sudah selesai serta siap di aplikasikan ke tanaman. Kegiatan ini di harapkan agar masyarakat mengetahui cara proses penyaringan terhadap pembuatan pupuk mol dan dapat meningkatkan pengetahuan yang lebih luas pada masyarakat Desa Toliba. Proses Penyaringan pupuk mol disajikan pada Gambar 3.
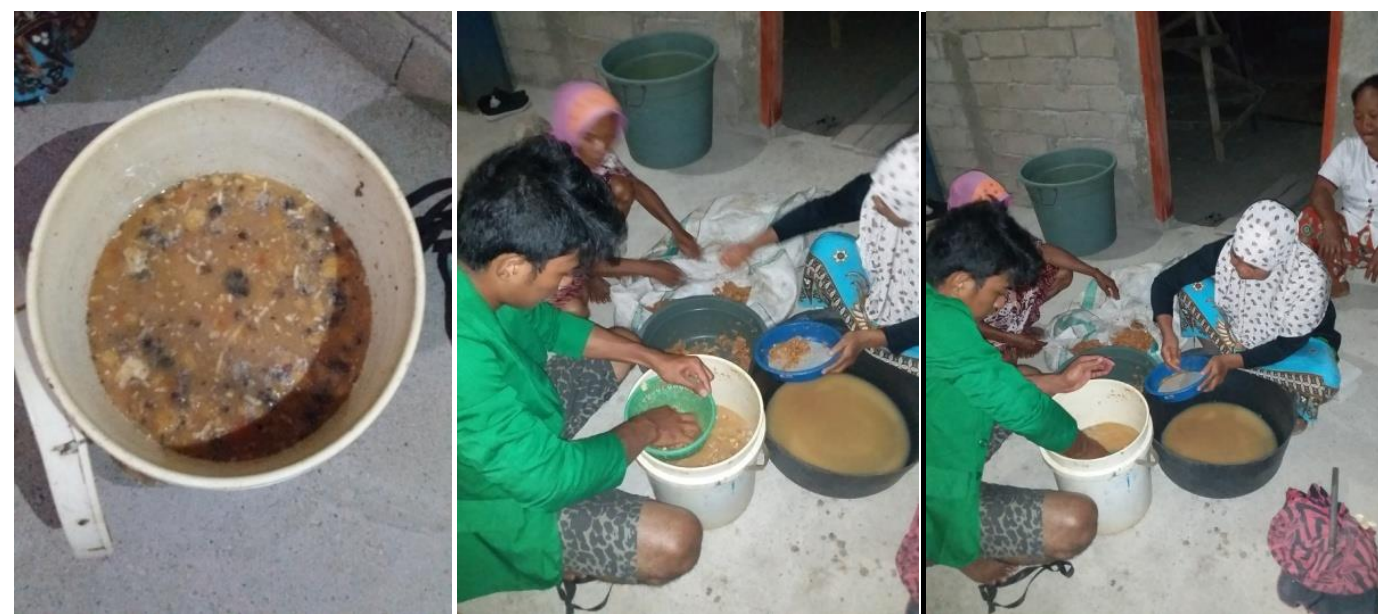

Gambar 3. Proses Penyaringan Pupuk Mol

\section{KESIMPULAN}

Dari hasil kegiatan pendampingan pembuatan pupuk Mol berbahan dasar bonggol pisang, rebung bambu dan buah pepaya di Desa Toliba Kecamatan Tojo Barat Kabupaten Tojo Una-una kepada masyarakat, dapat ditarik kesimpulan sebagai beriku:

1. Pelaksanaan program mampu menghasilkan luaran-luaran yang diharapkan oleh program pengabdian kepada masyarakat yakni meningkatnya pengetahuan masyarakat Desa Toliba dalam pembuatan MOL dengan memanfaatkan potensi yang ada. 
2. Meningkatnya pemahaman masyarakat tentang pemanfaatan bahan dasar (Bonggol Pisang, Rebung bambu dan Buah Pepaya) untuk dijadikan sebagai salah satu alternatif pupuk organik bagi tanaman.

\section{DAFTAR PUSAKA}

Budiyani, Ni Komang, Ni Nengah Soniasari, dan Ni Wayan Sri Sutari.

2016."Analisis Kualitas Larutan Mikroorganisme Lokal (MOL) Bonggol Pisang”.E-Jurnal Akroekoteknologi Tropika.Vol. 5, No. 1

Leonardo, M. 2009. Pengaruh Air Cucian Beras terhadap Pertumbuhan Tanaman Tomat dan Terung. www.portalgaruda.org. Diakses tanggal 16 Juni 2015.

Liferdi, L. 2008. Korelasi Kadar Hara Fosfor Daun dengan Produksi Tanaman Manggis. J. Hort. 18(3):283-292. www.portalgaruda.org. Diakses tanggal 29 September 2015.

Maspary, 2012. Membuat MOL rebung bamabu. http://gerbangpertanian.com.

Diakses pada 20 april 2015.

Mulyono, 2014." Membuat Mol dan Kompos dari Sampah Rumah Tangga". PT. AgoMedia Pustaka : Jakarta.

Nisa Khalimatu. 2016 Memproduksi Kompos dan Mikro Organisme Lokal (MOL). Jakarta: Bibit Publisher.

Supriyadi, A. 1991.Pisang Budidaya, Pengelolahan dan Prospek Pasar. Penebar Swadaya. Jakarta.

Suryanto, E. 2009. Air Kelapa Dalam Media Kultur Anggrek. (online). (http://wawaorchid.wordpress.com/2009.html). Diakses 12 Feb 2019 10:05:15 GMT. 